\title{
The Opinions Of The Secondary School Teachers Of Visual Arts On The Curriculum*
}

\author{
Gonca Erim \\ Uludağ University, Turkey \\ goncae@uludag.edu.tr
}

\author{
Müge Gültekin \\ Uludağ University, Turkey \\ mugegultekin@hotmail.com
}

Meltem Karakuyu Şangüder

Uludağ University, Turkey

meltemkarakuyu@gmail.com

\section{Berna Coşkun Onan}

Uludağ University, Turkey

onanberna@hotmail.com

\begin{abstract}
Based on the general objectives of Turkish National Education, the art curriculum in secondary education has been restructured in order to train individuals to be modern, rational, creative, devoted to national and historical values, and with aesthetic awareness. The works in curriculum development in education and the contemporary approaches to curriculum are also parallel with art education. The works that intend to improve quality in education involve analyzing the existing curriculums with the aim of restructuring those curriculums. In this context, the present work aims to justify changing the word "Painting" in the name of the secondary (high school) art curriculum and to highlight the functionality of this change. The explanation of this radical change in the curriculum based on the opinions of the people who experience the change directly reveals the importance of the present work. The present work also uncovers
\end{abstract}

\footnotetext{
* This study has been presented in the Anadolu International Symposium on Arts Education on the 14th -16th of May 2014, Eskişehir.
} 
how the people experiencing these changes explain them at planning, process of teaching and assessment phases on the basis of three basic learning domains: historical environment and museum awareness, the culture of visual arts and constructing forms in visual arts. In the present work, the study group was determined with the criterion of at least 10 year-teaching experience and semi-structured interviews, which were arranged to be held sequentially, were conducted for in-depth data collection. In the scope of qualitative method, the data gathered based on the phenomenological design have been explained by thematic analysis. The results that have been obtained are presented together with suggestions.

Key Words: Secondary school, Curriculum, Visual arts 


\section{Introduction}

Art education is a learning domain which enhances creativity and self-development in individuals by encouraging imagination. People with art education are aware of the sociocultural structure of the environment they live in, changing this awareness into sensitivity. They also aim to develop their culture and pass it on the next generations. In order to extend such consciousness in the society, art education should be a part of education at any level with curriculum designed according to students' personal development.

According to İnci San, art education means- unless specifically stated- education in plastic arts; since $20^{\text {th }}$ century, in broad sense it has defined creative artistic education inside or outside school including all areas of art, whereas in narrower sense it has referred to school and the courses related to art (San, 2010). The Art Curriculum in Secondary Education has been restructured as The Visual Arts Curriculum in Secondary Education in order to train individuals to regard art as part of life; able to appreciate a work of art and produce art using his/ her emotions, ideas and experiences; devoted to our historical and cultural values; with critical thinking ability; thinking globally; respectful to the nature and environment; loyal to Atatürk's reforms and principles; adopting the national, social and cultural values of Turkish nation; creative, self-confident, prolific, secular, pacifist and modern (M.E.B., 2009). It has been in use since 2010-2011 educational year and a follow-up to Primary Visual Arts Curriculum. The new curriculum was developed in accordance with the system in which visual arts has 2 hours per week. However, it has been mandatory for high-schoolers to take 2 hours of physical education since the 2009 legislation, whereas the class hours of visual arts and music has been reduced to 1 hour per week although the students were taught 2 hours of art, music and physical education until 2009-2010 educational year.

Although curriculum and syllabus may seem interwoven, Demirel defines syllabus as "the order of learning experiences provided for the students inside and outside of the school 
including all the activities to teach a course." (Demirel, 2005). Scientific and technological developments, improvements in teaching and learning in educational sciences, the need to enhance the quality and equality in education, the need to raise sensibility to individual and national values, the need to insure unity with primary visual arts syllabus, the necessity to ensure terminological coherence between the courses or within the course itself, new approaches to educational measurement and evaluation, and recent developments in art teaching justified restructuring the curriculum for the Ministry of National Education in Turkey.

"New developments in teaching and learning require reconstructing the learning process as student-centered" (Özden, 2005). Secondary Visual Arts Curriculum, whose aim is to train individuals to appreciate art rather than become artists, is based on student-centered approaches which enable them to be active, participating and inquisitive individuals. With the student-centered curriculum, it is aimed to be far from being academically repetitive and to prioritize individual learning, thereby making the student active, participating and inquisitive.

What is expected from the present education system is not to teach some specific knowledge and skills to the students but rather get an individual to acquire skills which help him/her come up with different ideas and produce works by making use of the knowledge, and apply these learning outcomes when necessary (Ayaydın, Vural, Tuna. \& Y1lmaz, 2009). Therefore, student-centered approaches are essential to art education.

Another educational approach on which the curriculum is based is active learning. As far as Kalem and Fer are concerned (2003):

“...It is about actively involving students in learning rather than making them passive audience and observer. However, students do not simply get involved in learning process but they are encouraged to use their mental skills, to think, 
Anadolu Journal of Educational Sciences International, Art Education Special Issue, November 2015

to make comments on what they have learned and to make a decision on learning process.”

Through active learning and student-centered approach, secondary students have an opportunity to improve their artistic expression and make new discoveries by experiencing freely.

The curriculum includes general objectives of the course, skills, values, learning domains, sub-learning domains, learning outcomes, activity examples, explanations, measurement and evaluation basics, Kemalism and calendar of days and events (M.E.B., 2009). It is divided into three learning domains: Visual Arts Culture, Construction in Visual Arts, and Historical Environment and Museum Awareness. Under these domains, art education subject areas are extended, and four art disciplines named "art criticism”, “art history", "aesthetics" and "applied studies" are combined and included in the curriculum. Acquisitions and activity examples have been prepared and presented accordingly. Students need active learning in all aspects. Through active learning in art education, various teaching methods in art criticism, art history, aesthetics and applied studies are actively used. The reason for that is the necessity that not only students with artistic talents but also those with different levels of artistic talents should have cultural knowledge. Both learning outcomes and activities are, therefore, prepared keeping this in mind.

"Current education system has a tendency to an approach based on students' knowledge rather than an approach focused on the whole class. This approach involves a student-centered learning instead of a teacher-centered one which can be experienced in an industrial and semi-information society." (Bulut, 2008). 
Art has become an essential part of education system due to national yearning for a better life. In order to train individuals to appreciate experience and create art, it has to have a more active role in student's education.

Restructured based on the idea that secondary students make artistic designs, understand art and artists, have creative thinking abilities, be respectful to the environment and preserve national values, it is believed that this curriculum will contribute to more effective learning outcomes thanks to active learning and student-centered approach in visual arts education.

\section{Methodology}

Research was carried out with qualitative methods. Data gathered from interviews were combined in phenomenological pattern. According to Yıldırım \& Şimşek (2008), phenomenology aims to explain concepts or situations that we experience and yet cannot make any sense of it. Accordingly, secondary art education curriculum can be defined as a phenomenon prepared based on several suggestions and justifications keeping in contact with the Ministry of National Education in Turkey, experts and secondary schools and yet its internal dynamics are not completely known. The situation that this phenomenon can be realized as it is aimed remains a complete mystery. So as to explain this mystery within the scope of some themes and provide a source for those who can benefit from it in different ways, opinions of the participants were used as far as specified criteria are concerned. It was possible to reckon on putting a process, which was theoretically planned by gathering and making sense of data collected with phenomenological research pattern, into practice.

\section{The Purpose of the Research}

The main purpose of the research is to evaluate the functionality of Secondary Visual Arts Curriculum, previously known as Secondary Art Curriculum, by the teachers who have taught 
both curriculums as far as some certain criteria are concerned. The following questions are to be answered in the research:

- What are the opinions of the Visual Arts teachers on the general framework of the restructured curriculum?

- What are the opinions of the Visual Arts teachers on the learning outcomes and activities included in the restructured curriculum?

- What are the opinions of the Visual Arts teachers on measurement and evaluation basics included in the restructured curriculum?

\section{The Importance of the Research}

As a result of experiencing this change in Secondary Visual Arts Curriculum for five years, we set out with the idea that those who experienced it may have made some deductions. Therefore, secondary teachers with at least 10 year-experience were interviewed. The process of reconstructing curriculums should be completed with evaluation of those experiencing it. Considering it will be beneficial to scrutinize different sub-categories of the curriculum and there are few qualitative studies on the topic, the research proves how important it is.

\section{Study Group}

Study group in the research was determined with criterion sampling, one of the purposeful sampling methods. Along with being voluntary, another criterion is that teachers should have at least 10 years of experience as s/he needs to have experienced both previous and current curriculum. All types of high schools in Bursa were within the general scope of the research. Of the general high schools, Anatolian and Science High Schools and Imam Hatip High Schools with visual arts in their teaching program, six teachers were chosen. 


\section{Collecting Data}

For six months when data were collected, all the researchers actively participated in interviews and curriculum analysis. In this process, the following are data collection tools that are thought to provide data for the analysis:

Semi-Structured Interviews: Interviews were considered as the basic data collection tool and thus five questions deriving from research questions were asked. Semi-structured questions were transcribed from authorized tape recordings.

Researchers' Notes: It is the notes that the researchers took during the interviews and the research itself. In this very research, the impressions that four researchers, who interviewed the teachers, got of the interviews and documents, and the writings about their judgments on research process were also used as data.

Curriculum Analysis: The curriculum was the backbone of data set in the research. Determining the interview questions to ask the teachers was used to reach some categories and themes in data analysis.

\section{Data Analysis Process}

An analysis based on data set is adopted in data analysis process (Yıldırım \& Şimşek, 2008). Data set comprises interview printouts, secondary visual arts syllabus and researchers' notes taken during interviews. Thematic analysis steps of Liamputtong (2009) are followed in data analysis process. The codes, categories and themes are obtained by cross-coding data source. Repeated sentences are crossed out in coding, and the focus is on the common ideas of the interviewees. The codes, which are obtained from interview data, are moved to themes taking researchers' notes and curriculum data into consideration. This process is maintained through all researchers' constant dialogues. Themes formed considering the whole data set are directly described. Nicknames are used in descriptions. 


\section{Validity and Reliability of the Research}

Diversification strategies are used to improve validity and reliability of the research. In this multi-author research, data resources are diversified through interviewing participants from different institutions while data collecting methods vary through interviews, researchers' notes and curriculum reading. Information about data collection and analysis are explicitly stated to improve reliability (Güler, Halıcıoğlu \& Taşğın, 2013). Tables are involved to ensure clarity. Validity of the research and each analysis step are controlled by each researcher separately considering code explanations and formation steps of themes. In order to improve internal validity in this multi-author research, all the codes are explained so as to avoid ambiguity. Then, researchers' analyses are compared and validity is calculated (Miles \& Huberman, 1994). The categories on which are not agreed are included in the related themes.

\section{Findings}

Findings of the research are organized in accordance with the research questions. Therefore, findings on the general framework of the curriculum are classified as "Superficial Art Education", "Flexibility" and "Guidance Function of the Curriculum”. Findings on the use of activity suggestions and learning outcomes of the curriculum are gathered under the themes "Determining Factors", "Activity Types" and "Achieving Learning Outcomes" whereas findings on measurement and evaluation approaches are combined under the theme “Measurement and Evaluation Complexity". 


\section{Findings on the General Framework of the Curriculum}

Table 1

Numerical analysis of the theme "Superficial Art Education" in the context of instructors' opinions

\begin{tabular}{llc}
\hline Categories of Superficial Art Education & $\boldsymbol{f}$ & $\boldsymbol{\%}$ \\
\hline Personal efforts against the negatives & 18 & 31 \\
Use of technology as a goal & 11 & 19 \\
Need to simplify the curriculum & 22 & 38 \\
Insufficient time & 7 & 12 \\
\hline 4 categories in total & 58 & 100 \\
\hline
\end{tabular}

The codes obtained from the opinions of the visual arts teachers on the general framework of the curriculum were gathered and categorized. Of these, the category "Personal efforts against the negatives" (31\%) can be explained with Özlem's view. She said:

"This [not teaching the course at school] needs solving, especially about art courses. Why is art not included in the curriculum but music is? In our school, for example, both courses are included and are simultaneously taught in separate rooms, dividing the class into two. This is a good way to deal with it...”

The opinions on the use of technology as a goal include the importance of how to acquire computer skills rather than choose activities for the use of smart boards and acquire artistic skills. "I give them performance assignments and they present it on the smart board. This is more fun and they get curious about it" said Serap (Serap, the 1st interview). However, İrem stated:

"We cannot make use of smart boards. The students cannot present their assignments on it. Moreover, you need to download software to use and not all 
students are able to do it. They need an extra training for that, too. They gave each student a tablet pc but the students play Candy Crush and have no idea how to use it." (İrem, the 1 st interview).

What she said show the importance she gave on the technology use in the classroom. Technology use in the classrooms as a goal requires extra training for those who use it, and for those who do not know how to use it, technology use in the classrooms as a goal consumes too much time due to lack of insufficient background knowledge (Researcher-1 Notes [R-1, $\mathrm{N}]$ ).

In the Secondary Visual Arts Curriculum, it is anticipated in the general objectives of the curriculum that students improve their creativity in their works using different techniques, keep up with the technology and utilize it in artistic works while it is expected in the skills that they make good use of information technology in order to put what they learn into practice in real life. As secondary students are deeply interested in technology, using educational technology effectively is one of the issues that the teacher should take into careful consideration in active learning process (M.E.B., 2009). It was found out from the interviews that the students cannot utilize technology in real life along with not being able to them in the classroom environment. Considering scientific and technological developments among the reasons why Secondary Visual Arts Curriculum was revised, there needs to be an effort for students to apply technology to artistic creativity process, not for the idea that students have to use technological tools only in presentations $(\mathrm{R}-3, \mathrm{~N})$.

The need to simplify the curriculum (38\%) contains the views that the curriculum is too comprehensive and intensive in comparison with the time allocated to the application by the Ministry of National Education in Turkey. Furthermore, determining factors in activity choices are lack of time, and physical and technological insufficiencies as opposed to student- 
centeredness or active learning which are suggested in the curriculum. Serap made a noteworthy remark on the need to simplify the curriculum:

"The subjects and activities are not consistent. It is suggested to use wire or wooden materials for 3-D works. These are not viable school-wise. If only there were more simple activities which are more practicable in a class hour and less expensive. We do not have most of these materials in our school. So, I tried using soap instead but...” (Serap, the 1st interview).

Whereas Ferda expresses her efforts to make the curriculum simpler in practice quoted "I sometimes have to skip some parts of the curriculum." (Ferda, the 1st interview), Özlem simplifies it combining the subjects based on time and students' interests:

"The topic is professions; timing is the first weeks of October in accordance with calendar of days and events; the main topic is definition of art and raising awareness about visual arts. So, I unite three topics: Atatürk, art and professions. Because it is the first week of the school, the students are asked to do some research on the topic and make a presentation. Here are some of the topics: The importance that Atatürk attached to art and art education; architect, art historian, graphic designer, painter, sculpture and etc. as professions related to art” (Özlem, the 1st interview).

Regarding this, it is stated in the Secondary Visual Arts Curriculum that teachers are able to do one or more than one activities in a class hour (M.E.B., 2009). The activities in the curriculum are possible to be combined. Moreover, the information that the activity includes learning outcomes of more than one sub-learning domains is provided using various symbols in the activity samplings $(\mathrm{R}-3, \mathrm{~N})$. 
The data obtained from teachers' opinions and researchers' notes proves that 'insufficient time" is one of the main reasons why secondary visual arts curriculum cannot be fully applied. Insufficient time category was mentioned by almost all the interviewees when they answered different interview questions in separate interviews. Part of these mentions is included in this category regarding achieving the curriculum and general assessment. Özlem made a notable comment on insufficient time:

"Later on, we move on to pattern design. Students copy figure design. Also, 1 hour per week is not adequate either for design or for foreshortening. In the first semester, there were some classes I had never taught for 4 weeks because of the exams. Lack of time is a big problem" (Özlem, the 1st interview).

There are some reasons for insufficient time which was highlighted by all the teachers. Weekly class hour was reduced to 1 hour from 2 hours as a consequence of the decisions made during the legal procedures the curriculum should undergo. In the curriculum that was put into practice after the legal procedures, there have been some problems to realize learning outcomes and to apply all the sub-learning domains as suggested (R-4, N).

Table 2

Numerical analysis of the theme "Flexibility" in the context of instructors' opinions

\begin{tabular}{llc}
\hline Categories of Flexibility & $f$ & $\boldsymbol{\%}$ \\
\hline Existence of the course in schools & 14 & 26 \\
In-house and inter-institution communication & 10 & 19 \\
In application of the Curriculum & 14 & 26 \\
In supervision mechanism & 4 & 8 \\
General objectives of the Curriculum & 11 & 21 \\
\hline 5 categories in total & $\mathbf{5 3}$ & $\mathbf{1 0 0}$ \\
\hline
\end{tabular}


Existence of the course in schools (26\%) indicates many problematic situations, some of which are administrative initiative to teach the course in the school, students' deprivation of visual arts due to its being elective course, and institutional support for its recognition as a relief for grade anxiety by both students and parents $(\mathrm{R}-1, \mathrm{~N})$. The most striking comment on this is made by Özlem:

"The most serious problem with this curriculum is that school principals do not fully comprehend this course. They are of the opinion that there is no need for workshops. It is in the legislation but no school principal follows it" (Zehra, the 1st interview).

It is concluded from the other supporting views that Zehra feels obliged to be content at least to be able to create a workshop for 15 students in her school and to reach her students (R-4, $\mathrm{N})$.

In-house and inter-institution communication (19\%) involves several codes. The first comment on the issue is by Serap:

"It took very long for this curriculum to be accredited by Turkish Education Board. It is still not accredited, though. We are allowed to use it so that there is a curriculum in hand. It was not handed in; we downloaded and printed it out, sharing with each other" (Serap, the 1st interview).

What Serap stated reveals the fact that it has not been solved with a problem-oriented approach via communication among the institutions although the curriculum has been in use for five years, along with a lack of training in its application $(\mathrm{R}-1, \mathrm{~N})$.

A comment on flexibility in application of the curriculum is made by İrem about the lack of training in the use of smart boards, tablet pc and other technological tools: 
Anadolu Journal of Educational Sciences International, Art Education Special Issue, November 2015

"Students should prepare presentations on tablet pc but they cannot. They also need software but school principals and inspectors are not aware of it. Some of the students are not able to type on Word, let alone recent technologies, which needs to be handled" (İrem, the 1st interview).

Flexibility in application of the curriculum (26\%) is another category under which positive or negative situations brought about by flexibility are combined, on which all the teachers have an opinion. As far as the researchers' impressions from all the interviews are concerned, flexibility in application of the curriculum results from the fact that it provides extra time to study other courses and exams for the students, that it is considered as free time activity, that school principals are indifferent to the course, and that physical environment of the school is not improved. Weighted high school Grade point Average (GPA) anxiety and preparation for university entrance exam have a great impact on the practicability of the learning domains in the curriculum. There are some teachers who consider this commonplace for senior students (R-2, N). Based on the findings, teachers' opinions are used to explain individual flexibility situations resulting from supervision mechanism (8\%). Of these opinions, the most striking one is by Serap:

"Now, some colleagues in other schools grade students by what students do in the class but I do not. Inspectors paid a visit to our school three years ago. I told the students that I would give them the highest grade (100 points) for performance assignment but they need to deserve it. They get happy" (Serap, the 1st interview).

The flexibility needs to be dealt in the scope of supervision mechanism when it inconveniences general objectives of education and art education. The codes of general objectives of education (21\%) differ significantly in terms of teachers' approaches. The objectives of secondary art education mentioned above overlap with and support general 
objectives of education. However, problems encountered in secondary schools defer achieving not only objectives of art education but general objectives of education as well. What Zehra stated is as follows:

"Our students get to good places in universities. They will form the systems in Turkey. Because they are very successful, they need to internalize art very well and appreciate it, which is my priority. When they graduate, I expect them to know how to appreciate art. Those who can do it learn many things and experience art, helping other experience it, as well" (Zehra, the 1st interview).

Serap emphasized individual flexibility saying that every teacher interprets the curriculum based on the circumstances and their experience and that they are indifferent to the achieving general objectives of education: "It is impossible for me to do everything included in the curriculum. Also, I already talked to the colleagues in other schools; they teach the parts they choose" (Serap, the 1st interview).

The analysis of the data obtained from the answers to the question "In which aspects do you think the curriculum guides you the most after it has been restructured?" are indicated in the table below.

Table 3

Numerical analysis of the theme "Guidance Function of the Curriculum" in the context of instructors' opinions

\begin{tabular}{llc}
\hline Categories of Guidance Function of the Curriculum & $\boldsymbol{f}$ & $\boldsymbol{\%}$ \\
\hline Suitable for the level, adequate and in order & 11 & 30 \\
Self-control & 5 & 13,5 \\
Obligatory simplification & 12 & 32 \\
Achieving learning outcomes & 4 & 11 \\
Activity preparation & 5 & 13,5 \\
\hline
\end{tabular}


Of the categories of the guidance function of the curriculum, the ideas on "suitable for the level, adequate and in order" (30\%) are "I use the complete curriculum as a guide." to Serap, "I make use of it to remember the topics and it encourages teachers to search." to Mert, and "It is intensive and its complete application depends on the fulfillment of necessary conditions" to Zehra. Considering all these opinions, it can be said that the curriculum is suitable for the level; however, it is not likely to refer to its functionality in guidance because there are some problems in application.

Here is Özlem's remark that makes one think that she considers it as a self-control mechanism $(13,5 \%)$ regarding the guidance of the curriculum:

"There was neither a proper curriculum nor a book to utilize. There was only one guideline prepared for Anatolian High Schools which I had been using. Thanks to this new curriculum, I have noticed that I was doing the right thing" (Özlem, the 1st interview).

The teachers complained about disorder in resource materials they used in the previous curriculum. It can be stated that they are now content with the order in these materials thanks to the restructured curriculum $(\mathrm{R}-2, \mathrm{~N})$.

İrem made a similar comment on guidance saying "I feel the need to look it up to find out how to make them acquire some learning outcomes" (İrem, the 1st interview). While İrem makes use of the curriculum to remember the learning outcomes and to find out how to reach all the learning outcomes $(11 \%)$, Serap uses the curriculum as a guide to activity preparation $(13,5 \%)$. According to Serap: 
"There are some suggestions, for instance, in choosing the subject. Let's say, the subject is the works of Contemporary Turkish artists and you introduce them to Contemporary Turkish artists. We make use of these suggestions" (Serap, the 1st interview).

One of the guidance functions of the curriculum is "obligatory simplification" formed by Ferda's idea that the curriculum has levels of difficulty, which is good, however, it is so intensive that it requires narrowing down in application. Other teachers often made similar comments (32\%). It can be concluded that teachers make good use of the curriculum to follow learning outcomes and general objectives while they decide on the subjects to teach regarding time and other conditions.

Findings on Activity Examples and Learning Outcomes in Secondary Visual Arts

\section{Curriculum}

Findings on the functionality of the use of activity examples and learning outcomes in the curriculum, data gathered from the answers to the questions "What do you think about preparing new activities based on the examples available in the curriculum?" and "What are your opinions about realizing all the learning outcomes included in learning domains in the curriculum?", and the analysis of the curriculum and researchers' notes are presented in the Tables 4, 5 and 6.

Table 4

Numerical analysis of the theme "Determining Factors" in the context of instructors" opinions

\begin{tabular}{llll}
\hline Categories of Determining Factors & $\boldsymbol{f}$ & $\boldsymbol{\%}$ \\
\hline Class Level & 12 & 21 \\
Arousing interest & 26 & 45 \\
Conditions & 20 & 34 \\
\hline
\end{tabular}


The codes from the opinions about activity examples and learning outcomes fall into different categories. "Class level" (21\%) includes the factors related to class level in choosing activities in visual arts course. Teachers decide what to teach regarding students' level of knowledge and perception. Serap stated that she gives more presentation assignments to hyperactive students and s/he prepares and presents it (Serap, the 2nd interview). Along with this, it is pointed out that originality is neglected since students with artistic talents actively participate in activities, as a result of which only artistic talent-oriented activities are performed.

"Arousing interest" (45\%) in the theme "Determining Factors" includes the methods used to encourage students to take part in activities in visual arts course. Among the methods used by the teachers are different material use, presenting historical differences together, technologywise applications, visuals, real-life experiences, group works, field trip and games. İrem stated:

\footnotetext{
"When I show them a Leonardo, I tell them his ratios, scientific personality and interest in science including his plane drawings. I specify the centuries they were made in. I emphasize that there was no internet or computers back then" (İrem, the 2nd interview).
}

The category "Conditions" (34\%) refers to the conditions under which visual art teachers realize activities in the curriculum. The codes in the "Conditions" involve two main issues, which are physical and technological conditions. İrem commented on the physical conditions affecting the activities:

"Facilities are important. There are four senior classes in our school, two of which I teach in workshops and the other two in classrooms. Teaching in workshop is a lot easier than in classroom" (İrem, the 2nd interview). 
İrem mentioned that there is storage problem as well as overcrowded classrooms and lack of workshops. The opinions about technological conditions are partly related to technological tools and partly students themselves. While İrem highlighted the importance of technology use in classroom, her dissatisfaction in the researcher's notes is as follows:

"Visual art teachers and students have various technological devices such as tablet pc, computer and smart boards); however, software incompatibility and technical insufficiencies of tablet pc exemplify the conditions under which visual art courses are performed. Student-oriented problems result from lack of technological training” (R-2, N).

Table 5

Numerical analysis of the theme "Activity Types" in the context of instructors' opinions

\begin{tabular}{llc}
\hline Categories of Activity Types & $\boldsymbol{f}$ & $\boldsymbol{\%}$ \\
\hline Based on students' research & 7 & 29 \\
Based on teacher's experience & 9 & 38 \\
Based on syllabus & 8 & 33 \\
\hline 3 categories in total & $\mathbf{2 4}$ & $\mathbf{1 0 0}$ \\
\hline
\end{tabular}

The categories under the theme "Activity Types" include the classification of activity examples of visual art teachers. Based on the teachers' interviews, three activity types are identified and categorized. Activity type "based on students' research" (29\%) is research paper, presentations, and performance assignments prepared by the student himself. "I provide them with the names of Contemporary Artists. They do some research on it and give a presentation. I evaluate these presentations" said Özlem (Özlem, the 2nd interview).

Activity type "based on teacher's experience" (38\%) is that teacher chooses activities based on his own experience rather than activity examples given in the curriculum. "I do any 
activity that comes to my mind." stated Serap (Serap, the 2nd interview). The idea that teachers form their own curriculum and use more familiar activities overlaps with flexibility regarding activities.

Activity type "based on syllabus" (33\%) is related to benefiting from activity examples given in the restructured Secondary Visual Arts Curriculum. As far as the related codes are concerned, teachers following the curriculum and teacher referring to it when necessary are involved. A teacher following the curriculum stated that thanks to the curriculum, he now teaches a subject he has never taught in his classes. It is, therefore, thought that the curriculum is beneficial to compensate for teachers' flaws $(\mathrm{R}-2, \mathrm{~N})$.

Table 6

Numerical analysis of the theme "Achieving Learning Outcomes" in the context of instructors' opinions

\begin{tabular}{lcc}
\hline Categories of Achieving Learning Outcome & $\boldsymbol{f}$ & $\boldsymbol{\%}$ \\
\hline Achieving learning outcomes & 21 & 57 \\
Needs & 16 & 43 \\
\hline 2 categories in total & $\mathbf{3 7}$ & $\mathbf{1 0 0}$ \\
\hline
\end{tabular}

"Achieving learning outcomes" and "Needs" are the categories formed with the teachers' opinions on activity examples and learning outcomes in the curriculum. "Achieving learning outcomes" (57\%) comprises of the views that all the learning outcomes are sufficient and yet it is not possible to achieve them all and it depends on the applicability, which contradicts with the comprehensive and intensive curriculum itself and timing. Here is a supporting view for the category:

"Learning outcomes are quite comprehensive. I include some of the very basic learning outcomes in my plan. I prioritize those included in the subject. 
However, I am not of the opinion that all the learning outcomes are achieved because of insufficient class hours" (Ferda, the 2nd interview)

It is an important detail that learning outcomes are not achieved because students cannot provide the materials stated in the syllabus $(\mathrm{R}-2, \mathrm{~N})$.

The codes related to the needs in order to achieve learning outcomes formed the category "needs" (43\%). Training is of vital importance regarding the needs to achieve learning outcomes in the curriculum as teachers stated that they feel inadequate in this area:

"Everything is included in the curriculum and yet not all art teachers own these materials or facilities. I, for instance, have never studied on sculptures. Art teachers can do a sculpture in-service training in universities. I have studied on printing techniques but some colleagues may not have. I believe these are necessary" (Zehra, the 2 nd interview).

There are other supporting ideas to this. Teachers avoid doing activities that they are not in good command of, which causes gaps in the curriculum $(\mathrm{R}-2, \mathrm{~N})$. The need for interinstitutional cooperation due to lack of equipment is stated along with the need for in-service training. Zehra said "We need to be able to use schools with furnace when we work on 3-D objects or clays. Institutions should cooperate" (Zehra, the second interview). Other factors affecting the achievement of all the learning outcomes are related to sufficient time and other physical environment.

\section{Findings on Measurement and Evaluation in Secondary Visual Arts Curriculum}

Findings on the functionality of the use of activity examples and learning outcomes in the curriculum, data gathered from the answers to the questions "What do you think about the measurement and evaluation approaches included in the curriculum?", and the analysis of the curriculum and researchers' notes are presented in the Table 7. 
Anadolu Journal of Educational Sciences International, Art Education Special Issue, November 2015

Table 7

Numerical analysis of the theme "Measurement and Evaluation Complexity" in the context of instructors'opinions

\begin{tabular}{llc}
\hline Categories of Measurement and Evaluation Complexity & $\boldsymbol{f}$ & $\boldsymbol{\%}$ \\
\hline Measurement and Evaluation Problems & 20 & 34 \\
Individual understanding & 38 & 66 \\
\hline 2 categories in total & $\mathbf{5 8}$ & $\mathbf{1 0 0}$ \\
\hline
\end{tabular}

In the "Measurement and Evaluation Problems" category (34\%), problems result from students, the course, curriculum and general education system. As in Zehra's statement that art course is neglected, student's prejudice and unwillingness to take part in the course are student-oriented problems. Regarding the problems related to the course, that other teachers gets students involved in the class by grading them contradicts with it while some teachers state that grading students is considered unnecessary because of the nature of art course. A teacher said that $9^{\text {th }}$ grade students were prejudiced against the course but in time they started to like it. She believes that grading is the reason why they began to like it (R-2, N). In regards with the problems caused by the curriculum, it is stated that it is difficult to put the curriculum into practice because evaluation criteria of the curriculum are too detailed. "Measurement and evaluation are too comprehensive in the curriculum. I, personally, do not evaluate students as given here. The procedure is long." said Özlem (Özlem, the second interview). Finally, the impact of weighted high school GPA on the evaluation of visual arts course, education policy of the Ministry of National Education in Turkey and the effect of students' compliance with the system on their success are listed among the problems resulting from education system. What Serap stated supports this idea:

"When inspector visited our school, he said that we were doing the right thing.

During inspection, a student showed him visuals and told him what this was. 
Anadolu Journal of Educational Sciences International, Art Education Special Issue, November 2015

The inspector said that there was nothing else to say and everything was correct. He also stated that the Ministry doesn't expect visuals, and we, teachers, should give students high grades" (Serap, the 2nd interview).

"Evaluating without measurement" code in "Individual understanding" category $(66 \%)$ is the most striking one. It appears that it is quite common to grade all the students in the class without doing anything. The statement below provides support to the idea:

"Everybody has different talents and skills. I believe we should not force students to do anything and give them the highest grades. I, myself, do so as long as they complete their work, which actually compels them. I tell them that I have done my part and it is their turn. They complete their work anyways" (Zehra, the 2nd interview).

Teachers with such an understanding believe that this enables students to learn empathy, sense of responsibility, and self-assessment. It is based on the contentment of the student, parent and the institution. According to the teachers interviewed, measurement and evaluation in visual art is equal to work assessment and it is a motivation for students to participate in the class.

Another point of view related to the category is to form one's own criteria for measurement and evaluation and follow them. Ferda explains it by saying:

"I have my own criteria to evaluate them. Do you take student's own progress into consideration or his progress in comparison to the class? Namely, what is your measurement strategy?" (Ferda, the 2nd interview).

Ferda emphasize the evaluation of a student's progress from $9^{\text {th }}$ grade through $12^{\text {th }}$ grade. On the other hand, Mert stated that he uses the criteria he gets from his colleagues. Timing, student's participation in the class and interest are also criteria for teachers (R-2,N). 


\section{Conclusion and Suggestions}

In this study, the functionality of the Secondary Visual Arts Curriculum is discussed in three different aspects: general framework and guidance, developing approaches to activity preparation, and achieving learning outcomes. The use of approaches to measurement and evaluation, which is included in the curriculum in a detailed way, is studied and data are analyzed and expressed. In the light of data obtained despite study group limitations, it is not highly likely to state that there is not any educational environment whose aim is to get students with artistic or different levels of talents artistically and culturally informed, and there is not much anxiety to create such an environment. Considering the reason for the restructured curriculum is to train individuals to appreciate art and be respectful to life, it is observed that the curriculum was reconstructed only in context and structure. The main reason can be that the desire to train individuals to be sensitive to art and life, which is among the general objectives of education, is not literally included in of each curriculum designed for all the levels of education. It can also be stated that the curriculum is not totally internalized and it fails its goals because of many in-house and inter-institutional problems. It is not expected for all the learning outcomes to be achieved due to insufficient class hour, lack of workshops and physical conditions. Consequently, the system in the application of the curriculum is said to be problematic when it is considered that it has been in use for five years and the problems have gradually become worse. In regards with data gathered in the research, suggestions are as follows:

- Encouraging seminars and sessions about visual arts can be held in the institutions to improve all the teachers' and students' motivation, and participation in these seminars and sessions can be obligatory as a part of evaluation to raise and maintain interest. 
- Meetings, seminars and sessions can more often be held for visual art teachers to share their ideas, problems and solutions to the achievement of learning outcomes, applicability of the curriculum and approaches to measurement and evaluation.

- More measures to compensate for physical and technological insufficiencies in institutions can be taken in order to do activity examples in the curriculum and to achieve all the learning outcomes.

- Class hour of visual arts course can be rearranged to be 2 hours a week in order to improve the practicability of the Secondary Visual Arts Curriculum, which is highly comprehensive and intensive.

- Visual arts course can be a required course, not an elective course so that not only students with artistic talents but also all the other students are taught art.

\section{References}

Ayaydın, A., Vural, Ü. D., Tuna, S. \& Yılmaz, G. M. (2009). Sanat Eğitimi ve Görsel Sanatlar Öğretimi. (Editors: Ali Osman Alakuş, Levent Mercin). Ankara: Pegem Publishing.

Bulut, İ. (2008). Yeni İlköğretim Programlarında Öngörülen Öğrenci Merkezli Uygulamalara İlişkin Öğretmen Görüşleri (Diyarbakır İli Örneği). Kuram ve Uygulamada Eğitim Yönetimi, 14(4), 521-546.

http://www.kuey.net/index.php/kuey/article/view/846, Access Date: 15.12.2013

Demirel, Ö. (2005). Kuramdan Uygulamaya Eğitimde Program Geliştirme. Ankara: Pegem Publishing.

Güler, A., Halıcıoğlu, M. H. \& Taşğın, S. (2013). Sosyal Bilimlerde Nitel Araştırma Yöntemleri. Ankara: Seçkin Publishing. 
Glesne, C. (2012). Nitel Araştırmaya Giriş (Translating editor: Ali Ersoy, Pelin Yalçınoğlu). (Original: 2011, 4th Edition). Ankara: Anı Publishing.

Kalem, S. \& Fer, S. (2003), Aktif Öğrenme Modeliyle Oluşturulan Öğrenme Ortamının Öğrenme, Öğretme ve Illetişim Sürecine Etkisi, Educational Sciences Theory \& Practise, 3 (2), 433-461.

http://www.sevalfer.com/files/Makale_AktifOgrenmeOrtami.pdf, Access Date: 18.12 .2013

Liamputtong, P. (2009). Qualitative data analysis: conceptual and practical considerations. Health Promotion Journal of Australia. 20(2), 133-139. http://www.halo.each.com.au/health-promotion/images/uploads/HPJAQual_Data_Analysis.pdf, Access Date: 17.12.2013

Miles, M. B. \& Huberman, A. M. (1994). An expanded sourcebook qualitative data analysis. (2nd Edition). California: Sage Pablications, Inc.

M.E.B. (2009). Ortaögrretim 9, 10, 11 ve 12. Sinıflar Görsel Sanatlar (Resim) Dersi Öğretim Programı. Ankara.

Özden, Y. (2005). Eğitimde Yeni Değerler. Ankara: Pegem Publishing. http://www.pegem.net/dosyalar/dokuman/16112007115837E\%C4\%9Fitimde\%20Yeni \%20De\%C4\%9Ferler.pdf, Access Date: 15.12.2013

San, İ. (2010). Sanat Eğitimi Kuramlart. Ankara: Ütopya Publishing.

Yıldırım, A. \& Şimşek, H. (2008). Nitel Araştırma Yöntemleri. Ankara: Seçkin Publishing. 